March 18, 2013 3:32 PM

\title{
Cyclical nature of Afghan fighting may mask deeper trends, experts warn
}

NATO troops have followed an annual rhythm in the Afghan War, referred to by Pentagon officials, the soldiers on the ground and journalists alike as the "fighting season." Generally, they describe it as beginning and ending with the warmer months. The lull is ascribed to snowbound mountain passes. But that common wisdom isn't exactly true, and may have distorted the real picture of how the war has evolved, one counterinsurgency expert says. He thinks the Taliban have begun hoarding their fighters over the warm months, biding their time until the Americans leave.

Military goods move between Pakistan and Afghanistan including mountain passes covered in snow. MCT

By Jay Price - McClatchy Newspapers

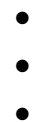

o LinkedIn

o $\underline{\text { Google }+}$

o $\underline{\text { Pinterest }}$

o $\underline{\text { Reddit }}$

o $\quad$ Print

- Order Reprint of this Story

On a blustery, subfreezing night in a sandbagged guard tower, Army Spc. Anthony Ross, 24, of Carson, Calif., twisted and spun in a brief dance. Sometimes Ross does push-ups on guard duty to stay alert, sometimes he dances.

His fellow boredom-fighter for the evening, Sgt. Ulisses Monteoncruz, 21, of Los Angeles, looked up, then went back to the tedium of scanning the rolling, muddy terrain behind the base through a night-vision device that rendered it in shades of gray.

Guard-tower duty is seldom exciting, and it's particularly tedious in Afghanistan in winter, as hundreds of American soldiers in towers across the country that same night were painfully aware. And Ross knew that in a week or two, when he'd rotate off tower duty back to his regular job - patrolling the roads to clear them of improvised bombs - there probably wouldn't be much action then, either.

For a little while. 
Scholars debate whether the war in Afghanistan has been America's longest, but as one last "combat season" is about to begin before most U.S. troops leave, there's little doubt that this war has been America's most cyclical.

For more than 11 years, U.S. and NATO troops have followed an odd annual rhythm, a pattern so obvious - whether measured in casualty figures or the number of insurgent attacks - that Pentagon officials, the soldiers on the ground and journalists alike casually refer to the annual "fighting season." Generally, they describe it as beginning and ending with the warmer months. The winter lull is ascribed to snowbound mountain passes that prevent insurgents from moving between their refuges in Pakistan and the fighting grounds in Afghanistan.

But that common wisdom isn't exactly true, and may have distorted the real picture of how the war has evolved, counterinsurgency expert David Kilcullen says. He thinks that the Taliban, hit hard by U.S. and NATO forces in recent years, may have begun cautiously hoarding their fighters over the warm months, biding their time until the Americans leave. Having fighters in reserve will strengthen their bargaining position with the U.S.-backed Afghan government so that they can negotiate the best possible terms in a settlement.

"The insurgents have been in a kind of permanent winter mode since 2010, and because of the election next year and everything else, they're on a different calculus now, where they basically are not thinking, 'How do I gain the most possible military advantage?' but instead, 'How do I preserve the largest possible force while still staying sufficiently engaged so as to maintain pressure on my opposite number in any future negotiation?" "

Kilcullen, who's been senior counterinsurgency adviser to Army Gen. David Petraeus in Afghanistan and Iraq, says the meaning of the combat lull is so misunderstood that he discourages the use of the term "fighting season" with anyone he works with on Afghanistan issues.

"It's not as simple as in summer they fight and in winter they don't," he said. "If you live through more than a year or two there, you realize that there are a couple of lulls. There's a lull that happens in sort of the April time frame. That's the poppy harvest lull, where there is genuinely a reduction in the fighting because people go and harvest their poppy."

The Taliban don't stop fighting in winter, Kilcullen says. They simply turn their energies from combat in the rural areas to terrorism in the towns and cities, targeting important local and national officials.

"I would say a better description of the seasonality is that the insurgency doesn't stop in the winter, it just goes urban," he said.

Casualties are indeed much higher in the warm months, but Kilcullen said that to focus on sheer numbers was a mistake. 
He cited the assassination attempt in December on Asadullah Khalid, the head of the Afghan domestic intelligence service, who was badly wounded. Khalid had built a reputation as a particularly aggressive foe of the Taliban.

"The sheer number of guys killed doesn't track to the importance of any given hit," he said. "If just three guys are killed in an attack, but those three guys killed were important Afghan ministers, that's big, and Khalid, even though he wasn't killed, that had a pretty significant political effect."

The war's characteristic cycles have another impact, said James Dobbins, a former U.S. special envoy to Afghanistan who's now the director of the RAND International Security and Defense Policy Center: They make it hard for a commander to track progress.

"It can lead to sort of false positives, where violence starts to go down and one thinks one has made progress until one remembers it goes down every year at this time," he said "So, instead of measuring yourself against a constant line, you have to measure yourself not against where you were last month, but where you were this same month last year. This means that each commander is not measuring his progress against his own previous experience, but against the previous commander's experience."

That also applies to combat troops, most of whom now serve a year or less in Afghanistan, and thus don't ever see two winter lulls. That means they can't build on their previous experience.

"People have described it as not being a 10-year war but rather 10 wars of one year each," Dobbins said. "There's something to that."

Kilcullen, who now runs Caerus Associates, a consultancy in Washington, thinks the summerwinter pattern also masks broader changes and trends, including changes in the way the Taliban are approaching the war.

"Right now, you've got guys at ISAF" - the International Security Assistance Force, the NATOled coalition - "saying, 'Well, we've broken the back of the insurgency. The operational defeat of the Taliban is accomplished, because are not seeing the guerrilla groups out in the countryside like we were two or three years ago,' " Kilcullen said. "But that's not necessarily true, right? It may be that they have gone to another mode of operating and we won't know for sure until the drawdown takes place."

As to the high mountain passes to Pakistan being closed by snow, Kilcullen doesn't believe that's the central reason for the winter drops in rural fighting. Pakistan aside, Afghans traditionally stay indoors as much as possible in the harsh winter months.

"Afghanistan, probably half of it is covered by snow every year for three or four months, and yet there is no evidence I have ever seen of any attempt at developing over-the-snow technology: no skis, no sleds, no skates, no snowshoes, nothing," he said. "So for thousands of years, no one has said, 'Hey, why don't we figure out some way of moving over it?' They all just basically sit down for four months." 
The first Western observation of a fighting season here referred only to the poppy harvest, Kilcullen said. It originated in the 1960s with Louis Dupree, an archaeologist and anthropologist from Greenville, N.C., who taught at Duke University and the University of North CarolinaChapel Hill, among other places, and was perhaps the best-known Western scholar of Afghanistan.

"One of the things he wrote about was how a rural society like Afghanistan can't farm and fight at the same time, so when it's harvest season or there are other major agricultural activities going on, you've go to stop fighting to do that," Kilcullen said. "So he sort of invented this idea that there's a fighting season and a farming season, and people tend to do one or the other, but it's very hard to do both."

For the record, the insurgents may fight more at some parts of the year and less at others, but the NATO-led coalition doesn't, said its spokesman, German Brig. Gen. Gunter Katz.

"ISAF doesn’t have a fighting season," he said. "We pressure them 365 days a year, 24 hours a day."

The predictable rhythms do have an upside, especially for new soldiers in rural Afghanistan who arrive in the quiet time. It gives them an opportunity to understand the environment they're fighting in before they're likely to have to engage in daily combat.

Spc. Ross and Sgt. Monteoncruz, who are serving as combat engineers with the 3rd Infantry Division in Zabul province, are among those.

"We arrived Jan. 25, for a nine-month tour, so we're seeing the lull, and the rise and the peak and then the fall," Ross said, as he listened to routine radio traffic from the other towers. "It's actually a pretty good thing, because this way the learning curve won't be bad at all, like it might be if we got dropped in right in the middle of the fighting season and things were just crazy."

He calls the lull "the Taliban's biggest mistake."

"It gives us time to learn what the routes are supposed to look like when everything is normal, and by extension what they shouldn't look like," he said.

Then he spun and peered intently into the darkness with his night-vision scope. Finally, some excitement: The tower door opened and the next guard shift stepped in, accompanied by one of the last frigid blasts of the quiet season.

Read more here: http://www.mcclatchydc.com/news/nationworld/world/article24746842.html\#storylink=cpy 